\title{
Energy Eficiency and Renewable Energy Solution in Telecommunication
}

\author{
Dr Borislav Odadzic ${ }^{1}$, Boban Panajotovic ${ }^{2}$, Dr Milan Jankovic ${ }^{3}$ \\ ${ }^{1,2,3}$ Republic Agency for Electronic Communication, Belgrade, Visnjiceva 8, Republic of Serbia \\ ${ }^{1}$ borislav.odadzic@ ratel.rs, ${ }^{2}$ boban.panajotovic@ ratel.rs, ${ }^{3}$ milan.jankovic@ ratel.rs
}

\begin{abstract}
The basic requirements for telecommunication power systems are related to their safety, long life and uninterruptible power (voltage). Power system based on renewable energy, design for power feeding of telecommunication equipment has to fulfill same requirements. The subjects of this paper are ICT impact on environment, energy efficiency and power system based on renewable energy requirements, design, calculation and sizing of its major part: photovoltaic cell, wind turbine, diesel generators and storage battery and "intelligent" control with focus on weather condition and battery status in this kind of system and benefits as: fuel consumption and $\mathrm{CO}_{2}$ emission reduction and logistic cost decreasing.
\end{abstract}

\section{Keywords}

Telecommunication, ICT, renewable energy, $\mathrm{CO}_{2}$ emission.

\section{Introduction}

The European Commission today called on Europe's information and communication technologies (ICT) industry to outline by 2011 the practical steps it will take to become $20 \%$ more energy efficient by 2015 . ICT equipment and services alone account for about $8 \%$ of electrical power used in the EU and about $2 \%$ of carbon dioxide emissions. But using ICT in a smart way could help reducing energy consumption and $\mathrm{CO}_{2}$ emission in energy-hungry sectors such as buildings, transport and logistics [1].

Due to new power and energy context such as greenhouse effect and other environmental issues, fuel depletion and electricity cost increase, new regulation and standards, telecom operators have to make efforts for using renewable energy solution [2].

In telecommunication the renewable energy sources, because of the high cost for Wh, are generally used in remote areas where the public mains is unavailable [2].

Renewable energy and energy efficiency solutions can present significant investment costs, which mean that Governments have to make efforts and create regulatory frame to stimulate investments in this area.

Because of ICT impact on environment, telecom operators have to use renewable energy and energy efficiency solutions wherever is possible.

Serbian Government also has to stimulate using of renewable energy sources and developing of these technologies. In telecom area, plan of Republic Agency for Electronic Communication is to promote and stimulate the use of renewable energy sources by telecom operator.

Such renewable energy sources are: Fuel Cells, Photovoltaic cell, Wind Turbine Generators, Micro hydro Generators, Stirling machine, fresh air cooling, etc.

In telecom application an efficient and reliable solution is to combine renewable and "traditional" energy sources.

Hybrid power system capture the best features of each energy resource and provide "grid-quality" electricity.

To achive uninterruptible power feeding of telecommunication equipment with quality power, hybrid power system includes energy storage system and redundant technology.

For hybrid power system design, the cites reliability studies play an important role, because it is necessary to keep the system at its best performance level [5].

This work will present requirements, design, calculation, sizing and "inteligent"control of hybrid system, which is combined from the next major part: Photovoltaic cell, Wind Turbine Generators, Diesel back-up generators and storage battery.

\section{Requirements}

The basic prerequisites imposed to telecommunication power systems are related to their safety, long life and uninterruptible power [6,7].

Energy efficient solution has to provide reduction of energy consumption. Clima system present critical component, which is directly related to the telecommunication equipment reliable operation. In some period, energy consumption of clima system can present significant part of total energy consumption at the location where telecommunication equipment is installed. Hybrid power system design for power feeding of telecommunication equipment has to provide quality uninterruptible voltage (AC, DC or both). In order to avoid very high costs, an optimization method should be used and good one is described in [8]. One of the major requirements is to design hybrid system cost effectly, with minimum exploitation costs.

\section{A. Outdoor cabinet design}

Outdoor cabinets are design to provide weather and mechanical protection. In some period (e.g. summer), 
internal clima system has important role in reliable operation of telecommunication equipment.

In now days, focus in outdoor cabinet design is on weather and mechanical protection. For the existing cabinet in operation, authors suggestions is to add additional cabinet made of panels with solid thermal insulation (glass wool, rock wool, polystyrene, urethane foam, vermiculite), as shown in figure 1. This solution will provide protection from direct insulation which causes temperature increasing in the cabinet. Benefits will be energy consumption decreasing and reliability of telecommunication equipment increasing.

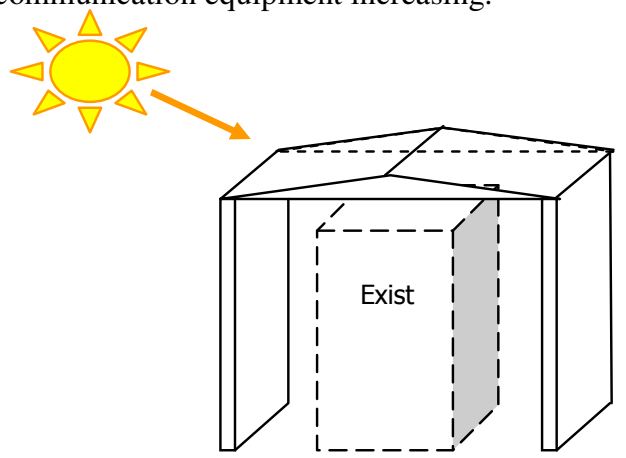

Fig. 1. Additional cabinet protection

For the new cabinet, authors suggestion is to be made from the panel with solid thermal isolation as: glass wool, rock wool, polystyrene, urethane foam, vermiculite, etc. Thermal insulation in outdoor cabinet is an important factor to achieving thermal comfort for installed telecommunication equipment.

For location with a lot of sunny days, outdoor cabinet can be made of two insulation layer, as shown in figure 2.

During exploitation period energy reduction is significant, and positive environmental effect can't be expressed in money.

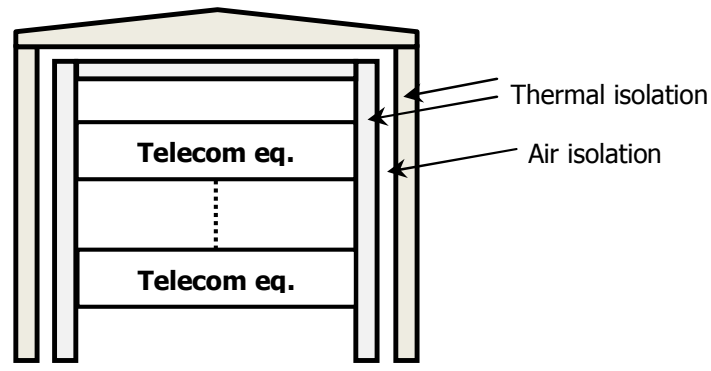

Fig. 2. Proposed cabinet construction

\section{B. Photovoltaic cell}

Sunlight may be used to generate electricity directly via photovoltaic cells. Problem is still high price per Watt of photovoltaic cells. One of the major requirements in hybrid power system design is to optimize size of cell. Many parameters have influence on photovoltaic cell design as: micro location, weather condition, preferred technology of photovoltaic cells, financial, etc.

\section{Wind Turbines}

The output power depends of wind velocity. If the wind speed changes very smoothly, the output power of wind turbine will also change very smoothly. On the other hand, wind turbulence causes the output power to fluctuate [3]. Requirements for wind turbines is to give constant output power as much as it possible in wide range of wind velocity. In Serbia, one of the problem for wind turbine appliance is missing of correct data for wind parameters as wind velocity and wind potential. Authors opinion is that project of wind mapping in Serbia has to be managed by Government institution. Suggestion is to perform measurement at 30,50 and 70 meters from the ground. Data on these altitudes provide information for most application of wind turbines.

\section{Energy Storage}

There are different types of energy storage (flywheel, battery, fuel cell etc.). The energy storage behaves like a large buffer to accommodate the unequal instantaneous energy in power system [3]. In hybrid power system which is subject of this work, battery used like energy storage system work in daily charging and discharging. Basic requirement for this battery is "high" number of cycling. Opposite, replacing of battery can present significant exploitation costs, which is not environment friendly. Critical point is choosing of battery technology. Different technology means different parameters as: life time, number of cycles, resistivity to depth discharged, etc. Table 1 present typical battery characteristics, depends of technology. Also different technology mean different price per Ah.

\section{E. Diesel back-up generators}

Conventional back-up generators are normally diesel engine directly coupled to synchronous generators. In hybrid power system which is subject of this work, diesel back-up generator has to ensure uninteruptibility of the system. One of the requirements is to optimize size of generator and to minimize fuel consumption and carbon dioxide emissions. 
Table 1: Overview of typical battery characteristics

\begin{tabular}{|c|c|c|c|c|c|c|c|c|}
\hline \multirow[t]{2}{*}{ Type } & \multirow[t]{2}{*}{ Electrolyte } & \multirow{2}{*}{$\begin{array}{c}\text { Faradic } \\
\text { Efficiency } \\
(\%)\end{array}$} & \multirow{2}{*}{$\begin{array}{c}\text { Energy } \\
\text { efficiency } \\
{[\%]}\end{array}$} & \multirow{2}{*}{$\begin{array}{c}\text { Energy } \\
\text { density } \\
{[\mathrm{Wh} / \mathrm{kg}]}\end{array}$} & \multicolumn{2}{|c|}{ Power densities } & \multirow{2}{*}{$\begin{array}{c}\text { Life cycle } \\
\text { [cycles } \\
\text { number] at } \\
20^{\circ} \mathrm{C}\end{array}$} & \multirow{2}{*}{$\begin{array}{c}\text { Operating } \\
\text { temperat. } \\
{\left[{ }^{\circ} \mathbf{C}\right]}\end{array}$} \\
\hline & & & & & $\begin{array}{c}\text { Peak } \\
\text { (W/kg) }\end{array}$ & $\begin{array}{c}\text { continuous } \\
(\mathrm{W} / \mathrm{kg})\end{array}$ & & \\
\hline $\begin{array}{l}\text { Lead-acid } \\
\text { LA }\end{array}$ & $\mathrm{H}_{2} \mathrm{SO}_{4}$ & Up to $99 \%$ & 75 to $90 \%$ & $20-35$ & 120 & 25 & $500-2000$ & -20 to 60 \\
\hline $\begin{array}{l}\text { Nickel- } \\
\text { Cadmium } \\
\mathrm{Ni}-\mathrm{Cd}\end{array}$ & $\mathrm{KOH}$ & Up to $99 \%$ & 70 to $87 \%$ & $40-60$ & 300 & 140 & $500-2000$ & -40 to 60 \\
\hline $\begin{array}{l}\text { Ni-metal- } \\
\text { hydrid } \\
\text { Ni-MH }\end{array}$ & $\mathrm{KOH}$ & Up to $99 \%$ & 70 to $87 \%$ & $60-80$ & 440 & 220 & $500-2500$ & 10 to 50 \\
\hline $\begin{array}{l}\text { Lithium-ion } \\
\text { Li-ion }\end{array}$ & $\mathrm{LiPF}_{6}$ & Up to $99 \%$ & 70 to $95 \%$ & $100-200$ & 720 & 360 & $500-4000$ & -20 to 60 \\
\hline
\end{tabular}

\section{System design}

Many methods and algorithms are developed for Hybrid power system modeling, design and components sizing. For optimal modeling, design, calculation and components sizing is essential to have precise micro location meteo data and to define system reliability in power feeding. A detailed study of the above factors is the first step to choose the required system topology and to make the best of the local potentialities to supply the telecommunication equipment [5].

Optimization in hybrid power system present focal point. Optimization for hybrid system describe in this paper means that system is design cost effectly and exploitation costs, maintenance costs, replacing costs of system components (e.g. battery) are minimize in period of exploitation (longer than 20 years). Appeal for system reliability has large impact on the system price and system optimization.

For example, hybrid power system can be modeled with a high degree of accuracy considering the highly complex working of actual systems. Optimization algorithms change the values of decision variables of an underlying in model in such a way as to optimize the resulting value of the model's objective function [4].

Calculation and sizing has to be done according next basic parameters and requirements: geographical location, meteo data, temperature range, period of insulation per year, average period of insulation per day, required voltage, required autonomy of Diesel generator back-up, required autonomy of battery back-up, etc.

This parameters and requirement has big influence on hybrid power system price.

For example, in region with no constant meteo condition during all year, longer autonomy - higher battery capacity is recommended. It requires higher battery charging current. If diesel generator back-up fuel consumption has to be minimized, energy for battery charging has to be provided from photovoltaic cell which present most expensive component in the system. The energy for battery charging can also be provided from wind generator.

This is the reason why meteo data for micro location has to be precise. Correct data is necessarily for system optimizing.

\section{Calculation and component sizeing}

In this work calculation and component sizing are based on DC current and 48VDC nominal voltage. Converters efficiency will not be taken in consideration, because it is not essentially for this work.

Generally is very important to predict all converters in system with higher efficiency. In total, it present significant reduction of energy. Converter design means more or less quality of convertor parameters (e.g. output voltage, disturbance, ripl, peaks, harmonics). This is very important in system which work parallel with public mains and part of energy from renewable sources is deliver to the public mains.

Figure 3 shows hybrid power system described in this work.

\section{A. Capacity of battery}

Required minimal capacity of battery can be calculated according formula:

$$
\mathrm{Q}_{\min }=\left(\mathrm{I}_{\mathrm{DC}} \times \mathrm{T} \times \mathrm{K}_{1}\right)(\mathrm{Ah})
$$

where $\mathrm{I}_{\mathrm{DC}}$ is telecommunication equipment DC current, $\mathrm{T}$ is required authonomy, $\kappa_{1}$ is coeffitient for battery capacity increasing depend of plate sulfatisation and low temperature $(1,15)$.

In this system, required autonomy will be ensured with two parallel Lead-acid 48V batteries in GEL technology. GEL technology present balans between price, number of 
maximum cycles and resistivity on deep discharge. Important characteristic of GEL battery is higher charging current. Higher charging current means shorter charging time. Opposite, higher charging current means decreasing of battery life time and increasing of operational costs. In this work is described "intelligent" control. Battery current is usually set on fix value. System "intelligent" control change this value depends of battery status and "real" meteo condition.

Current for battery charging

Battery manufacturer usually recommend maximum $0,10 \quad C_{10}$ battery current for battery charging. Some manufacturers, for their battery allowed $0,15 \mathrm{C}_{10}$ battery current for battery charging.

\section{B. Area of photovoltaic cell}

Many authors developed different methods and algorithm for optimizing of photovoltaic cell. In hybrid power system, sizing of photovoltaic cell present critical point because of its price.

Principe is to provide energy from photovoltaic cell for load feeding and battery charging.

In this work requirements for photovoltaic cell are defined for summer period. Sizing will be done according to these requirements.

Day (24h) will be split in two periods. First period, with maximum insulation (in this period photovoltaic cell provide maximum power), second period totally black out, no energy from photovoltaic cell.

Requirements for photovoltaic cell in first period are to provide energy for telecommunication equipment power feeding and energy for battery charging. In period of insulation, battery must be charged with enough energy to provide back-up autonomy in pre-defined period with no sun (e.g. 2 days). Energy can be provided from diesel generators also, but the target is to reduce fuel consumption of diesel generators. Bigger area of photovoltaic cell means more energy during other season also, not only summer. Final results are total operation cost and $\mathrm{CO}_{2}$ emission decreasing.

For optimal photovoltaic cell sizing is necessary to have "real" insulation data in period for micro location where system will be install.

Authors proposed two methods for photovoltaic cell sizing.

\section{I method}

In this method, calculation will determine energy from photovoltaic cell in period of insulation during summer season, for telecommunication equipment power feeding and for energy storage in battery [9]. Energy stored in battery is determined for pre-define required autonomy.

$$
E_{P V}=I_{D C} \times U_{D C} \times T_{\text {ins }}+I_{D C} \times U_{D C} \times T_{\text {back-up }}
$$

where $\mathrm{I}_{\mathrm{DC}}$ is telecommunication equipment $\mathrm{DC}$ current, $\mathrm{U}_{\mathrm{DC}}$ is nominal voltage $(48 \mathrm{~V}), \mathrm{T}_{\mathrm{ins}}$ is period of insulation and $\mathrm{T}_{\text {back-up }}$ is required time for battery back-up.

Required power from photovoltaic cell in period of insulation is:

$$
\mathrm{P}_{\mathrm{PV} 1}=\mathrm{E}_{\mathrm{PV}} / \mathrm{T}_{\mathrm{ins}}
$$

Area of photovoltaic cell $\left(\mathrm{S}_{\mathrm{PV} 1}\right)$

For optimal area of photovoltaic cell calculation is important to have technical characteristics of photovoltaic cell. Different technologies means different characteristics and price.

E.g. monocristal photovoltaic cell has higher energy (power) density per $\mathrm{m}^{2}$ than polycristal, but price is also higher.

In this example where day is split in two period necessary parameter is peak power per $\mathrm{m}^{2}\left(\mathrm{P}_{\mathrm{m}}{ }^{2}\right)$ of photovoltaic cell.

$$
\mathrm{S}_{\mathrm{PV} 1}=\mathrm{P}_{\mathrm{PV} 1} / \mathrm{P}_{\mathrm{m}}{ }^{2}
$$

\section{II method}

In this method, calculation will determine power from photovoltaic cell required for telecommunication equipment power feeding and for battery charging with maximum current $\left(0,15 \mathrm{C}_{10}\right)$ [9].

$$
\mathrm{P}_{\mathrm{PV} 2}=\mathrm{I}_{\mathrm{DC}} \times \mathrm{U}_{\mathrm{DC}}+\mathrm{I}_{\mathrm{battmax}} \times \mathrm{U}_{\mathrm{DC}}
$$

where $\mathrm{I}_{\mathrm{DC}}$ is telecommunication equipment $\mathrm{DC}$ current, $\mathrm{U}_{\mathrm{DC}}$ is nominal voltage $(48 \mathrm{~V})$ and $\mathrm{I}_{\text {battmax }}$ is maximum battery charging current $\left(0,15 \mathrm{C}_{10}\right.$ in this work).

Area of photovoltaic cell $\left(\mathrm{S}_{\mathrm{PV} 2}\right)$

As explained, necessary parameter is peak power per $\mathrm{m}^{2}$ $\left(\mathrm{P}_{\mathrm{m}}{ }^{2}\right)$ of photovoltaic cell..

$$
\mathrm{S}_{\mathrm{PV} 2}=\mathrm{P}_{\mathrm{PV} 2} / \mathrm{P}_{\mathrm{m}}^{2}
$$

\section{Conclusion for photovoltaic cell area}

Both calculated areas of photovoltaic cell fulfill defined requirements. Decision for adopting is based on different facts as price, real meteo micrlocation condition, operational costs, etc.

In this work authors proposed photovoltaic cell with bigger area. Reason is reduction of diesel generator fuel consumption and $\mathrm{CO}_{2}$ emission, decreasing of logistic 
costs and to present "intelligent" control in hybrid power system..

Generally, smaller area of photovoltaic cell can be applied. Problem in the system with smaller area of photovoltaic cell is the increase of fuel consumption and $\mathrm{CO}_{2}$ emission. Also, logistic operational cost increase, more visit of location for diesel generator tank filling and services, more training person needed, etc.

\section{Power of wind turbine}

In hybrid power system with solid area of photovoltaic cell, price of wind turbine is minor compared with the price of the other system component.

Basic parametar is power of wind turbine. Other parameters and working characteristics depend mostly of microlocation wind potential, wind velocity, etc.

Wind turbine in this work is defined to feed telecommunication equipment and to charge battery with maximum current $\left(\mathrm{I}_{\text {battmax }}=0,15 \mathrm{C}_{10}\right)$.

Output power of wind turbine depends of wind velocity. Based on wind potential in micro location where system will be install, type and characteristics of wind turbine will be determine.

\section{Diesel back-up generators}

Diesel back-up generators will be used in situation without sun and without wind, when the back-up battery is discharged.

Diesel back-up generators in this work is defined to feed telecommunication equipment and to charge battery with maximum current $\left(\mathrm{I}_{\text {battmax }}=0,15 \mathrm{C}_{10}\right)$.

Positive fact is that already, at many telecommunication location diesel back-up generators are installed, or they are planed for installation at future location.

General authors recommendation is to use diesel back-up generators bigger then $10 \mathrm{kVA}(\cos \varphi=0,8)$, for power feeding of telecommunication equipment or the other critical application. "Smaller" diesel back-up generators have not quality speed and voltage regulator, it cause unstable voltage and frequency. Also, there is no possibility to use sophisticate system for diesel back-up generators control and monitoring.

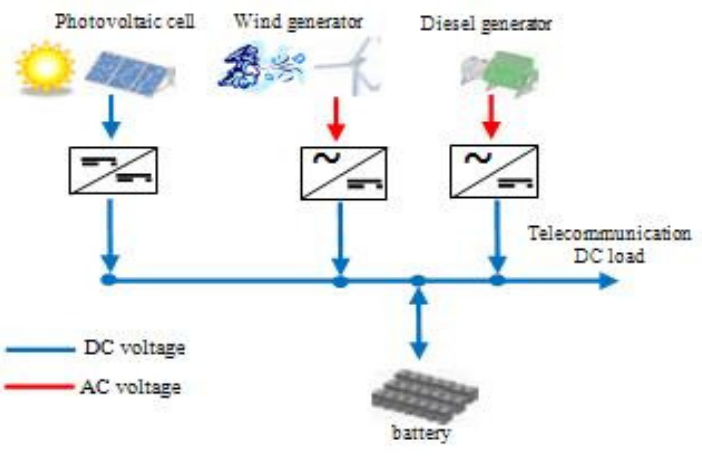

Fig. 3. Hybrid power system
Authors suggestion is to equip diesel back-up generators with additional season tank. Daily tank is insufficient for application with no grid connection. Without additional (season) tank, in some periods (e.g. during winter), it can cause: operational and logistic costs to increase, and reliability to decrease.

\section{Principle of hybrid power system operation}

Principle of hybrid power system operation is to provide energy from photovoltaic cell and wind generators for telecommunication equipment (load) power feeding and battery charging if it is possible.

If energy from photovoltaic cell or wind generator is not sufficient for battery charging, only telecommunication equipment (load) will be fed by renewable energy.

If renewable energy sources (sun and wind) is not sufficient for load power feeding, difference of energy is provide from battery, or from diesel back-up generator if battery is discharged.

When diesel back-up generator fed load, it means that battery is discharged.

Battery must be protect from over discharge by low voltage disconnection (LVD). The rating of low voltage disconnection is set as fix value (typically 1,8 V/cell, or $1,75 \mathrm{~V} /$ cell). Also, maximum battery charging current is set as fix value (typically $\mathrm{I}_{\text {battmax }}=0,10 \mathrm{C}_{10}$ ).

According described algorithm, most hybrid power system composed from photovoltaic cell, wind generators, diesel back-up generators and battery operate.

\section{Control of hybrid power system}

Principles of hybrid power system control is based on algorithm described in previous chapter. If energy from renewable sources is not sufficient, energy is provided from battery or diesel back-up generator. First back-up source is battery, then diesel generator.

Battery has to be charge quickly as it possible. Period of battery charging is longer if charging current is "smaller". Opposite, period of battery charging is shorter if charging current is "higher", but this can cause reduction of battery lifetime.

In typical hybrid power system "real" battery status (battery condition) is not take in consideration.

In this chapter, authors will explain proposed princip of "intelligent" control in hybrid power system, based on battery status (battery condition) and "real" meteo condition for location where system is installed [9].

Parameters important for battery operation as low voltage disconnection and maximum battery charging current are usually set on fix value. In this work, those parameters are programmable (changeable). 
For this approach, two requirements have to be fulfilled:

-Battery has to be monitored, and 2 capacities have to be calculated based on monitor information. Actual capacity $\left(\mathrm{C}_{\mathrm{a}}\right.$ present instantly capacity of battery) and capacity of fully charged battery (percentage of nominal capacity). Battery can be safely used until capacity of fully charged battery is higher than $80 \%$ of nominal capacity $\left(\mathrm{C}_{\mathrm{n}}\right)$. If capacity of fully charged battery is nearby nominal capacity, higher charging current and lower level of LVD allowed.

-Weather parameters as air temperature, relative humidity, barometric pressure, wind velocity have to be measured, at present micro location. Now days technology enable, based on this value, to have very precise short term weather forecast. With measurement of these parameters, few days weather forecast is accurate too.

Also, in concept of "intelligent" control is not predefined power feeding from diesel generator or battery. Based on battery status (battery condition) and "real" meteo condition control logic will "take decision" what is primary back-up source, or in some situation is it needed to charge battery from diesel generator.

Figure 4 shows "intelligent" control of hybrid power system described in this chapter, without central battery charger.

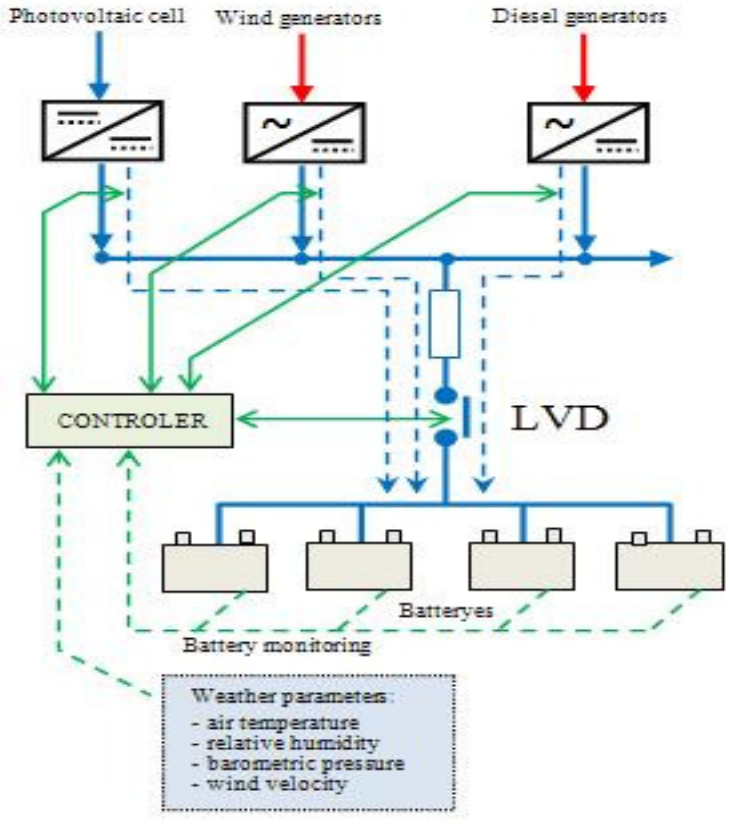

Fig. 4. Intelligent control of hybrid power system

\section{Conclusion}

In now days consensus has been reached among the scientists, energy engineers and economists as well as political communities all over the world that there is a need to supply energy for all sectors, including ICT without a detrimental impact on ecology and environment.

In this work, for telecommunication application has been suggested to use energy efficient solution and renewable energy in combination with traditional, to provide stable and reliable energy sources.

Using of renewable energy is proposed not only for remote sites in off-grid application. Wherever is possible is needed to use renewable sources, like in data or telecom center. In-grid application are possible to.

After presenting of the components of described hybrid power system and their sizing, authors present idea of "intelligent" hybrid power system control.

Presented idea of "intelligent" hybrid power system control, for target has reducing of fuel consumption and $\mathrm{CO}_{2}$ emission, decreasing of logistic and operational costs and cost effective component sizing.

Future work will be focused on new working algorithm development. This algorithm will be base on real meteo data, which means number of variety and system adoption for short term and long term period.

Generally, purpose of this work is to give some practical guideline, stimulate development of new idea in this area and promote using of this technology.

\section{References}

[1] European Commision Repport, IP/09/1498, Brussels, 9. October 2009.

[2] ETSI Technical Repport ETSI TR 102 532, The use of alternative energy solution in telecommunication installation.

[3] E. Muljadi and J.T. Bialasiewicz, "Hybrid power System with a Controlled Energy Storage", $29^{\text {th }}$ Annual Conference of the IEEE Industrial Electronich Society, Roanoke, Virginia, November 2003.

[4] Seeling-Hochmuth, "Optimisation of hybrid energy systems sizing and operation control", PhD thesis , Universiti of Kassel, October 1998.

[5] E.F.E. Ribeiro, A.J. Marques Cardoso and C. Boccaletti "Uninterruptible energy production in standalone power systems for telecommunication", International conference on renewable energies and power quality, Valencia, April 2009.

[6] Reeve, "DC Power system design for telecommunication", John Wiley and Sons, USA (2007).

[7] Gumhalter, "Power supply in telecommunications", Springer-Verlag, Berlin (1995).

[8] D. B. Nelson, M.H. Nehrir and C. Wang, "Unit sizing of standalone hybrid wind/PV/fuell cell power generator system", IEEE Power Engineering Society Meeting 2005, Vol. 3, pp 2116-2122, June 2005.

[9] B. Panajotovic and B. Odadzic, "Design and "Inteligent" Control of Hybrid Power System in Telecommunication, IEEE Conference Melecon 2010, Valleta, April 2010. 